The International Journal of

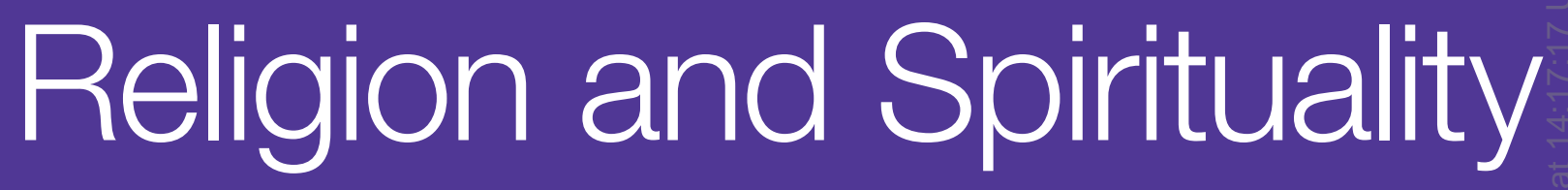

in Society

The Significance of Communal Religious Freedom for Liberal Democracy

HANS-MARTIEN TEN NAPEL 


\section{EDITOR}

Luis G. Roger-Castillo, University of Granada, Spain

HEAD OF JOURNAL PRODUCTION

McCall Macomber, Common Ground Research Networks, USA

\section{EDITORIAL ASSISTANT}

Hannah Werner, Common Ground Research Networks, USA

\section{ADVISORY BOARD}

The Religion in Society Research Network recognizes the contribution of many in the evolution of the Research Network. The principal role of the Advisory Board has been, and is, to drive the overall intellectual direction of the Research Network. A full list of members can be found at http://religioninsociety.com/about/advisory-board.

\section{PEER REVIEW}

Articles published in The International Journal of Religion and Spirituality in Society are peer reviewed using a two-way anonymous peer review model. Reviewers are active participants of the Religion in Society Research Network or a thematically related Research Network. The publisher, editors, reviewers, and authors all agree upon the following standards of expected ethical behavior, which are based on the Committee on Publication Ethics (COPE) Codes of Conduct and Best Practice Guidelines. More information can be found at:

THE INTERNATIONAL JOURNAL OF RELIGION AND SPIRITUALITY IN SOCIETY http://religioninsociety.com

ISSN: 2154-8633 (Print)

ISSN: 2154-8641 (Online)

http://doi.org/10.18848/2154-8633/CGP (Journal)

First published by Common Ground Research Networks in 2018 University of Illinois Research Park

2001 South First Street, Suite 202

Champaign, IL 61820 USA

$\mathrm{Ph}:+1-217-328-0405$

http://cgnetworks.org

The International Journal of Religion and Spirituality in Society is a peer-reviewed, scholarly journal.

\section{COPYRIGHT}

(C) 2018 (individual papers), the author(s)

(C) 2018 (selection and editorial matter),

Common Ground Research Networks

\section{(이)( $)=$}

Some Rights Reserved

Public Licensed Material: Available under the terms and conditions of the Creative Commons Attribution-NonCommercial-NoDerivatives 4.0 International Public License (CC BY-NC-ND 4.0). The use of this material is permitted for non-commercial use provided the creator(s) and publisher receive attribution. No derivatives of this version are permitted. Official terms of this public license apply as indicated here: https://creativecommons.org/licenses/by-nc-nd/4.0/legalcode

\section{Crossref}

$\mathrm{http}: / /$ religioninsociety.com/journal/model.

\section{ARTICLE SUBMISSION}

The International Journal of Religion and Spirituality in Society publishes quarterly (March, June, September, December). To find out more about the submission process, please visit $\mathrm{http}: / /$ religioninsociety.com/journal/call-for-papers.

\section{ABSTRACTING AND INDEXING}

For a full list of databases in which this journal is indexed, please visit http://religioninsociety.com/journal.

\section{RESEARCH NETWORK MEMBERSHIP}

Authors in The International Journal of Religion and Spirituality in Society are members of the Religion in Society Research Network or a thematically related Research Network. Members receive access to journal content. To find out more, visit http://religioninsociety.com/about/become-a-member.

\section{SUBSCRIPTIONS}

The International Journal of Religion and Spirituality in Society is available in electronic and print formats. Subscribe to gain access to content from the current year and the entire backlist. Contact us at support@cgnetworks.org.

\section{ORDERING}

Single articles and issues are available from the journal bookstore at https://cgscholar.com/bookstore.

\section{HYBRID OPEN ACCESS}

The International Journal of Religion and Spirituality in Society is Hybrid Open Access, meaning authors can choose to make their articles open access. This allows their work to reach an even wider audience, broadening the dissemination of their research. For more, please visit http://religioninsociety.com/journal/hybrid-open-access.

\section{DISCLAIMER}

The authors, editors, and publisher will not accept any legal responsibility for any errors or omissions that may have been made in this publication. The publisher makes no warranty, express or implied, with respect to the material contained herein. 


\title{
The Significance of Communal Religious Freedom for Liberal Democracy
}

\author{
Hans-Martien ten Napel, ${ }^{1}$ Leiden Law School, The Netherlands
}

\begin{abstract}
Leading US scholar of constitutional interpretation Michael Paulsen has developed an interesting theory of religious freedom called "The Priority of God." Paulsen distinguishes, first of all, a liberal conception of religious freedom, according to which it is widely assumed that religious truth exists in a society and the state is tolerant towards various faiths and other traditions. The US, however, has developed in the direction of a modern conception of religious freedom, which no longer recognises religious truth although the state remains tolerant. Moreover, still according to Paulsen, several European countries have adopted a postmodern conception of religious freedom. This conception does not only no longer recognise religious truth, but also implies a considerably less tolerant state, as secularism becomes the established "religion." This view paradoxically resembles the preliberal stance of religious intolerance out of the conviction that religious truth exists. In response to such developments, the current article makes a case for the classical liberal position with respect to religious freedom. A liberal religious freedom conception forms the best guarantee that societal institutions will be able to fulfil their constitutional functions of a check on the government and as "seedbeds of virtue."
\end{abstract}

Keywords: Religious Freedom, Liberal Democracy, Separation of Powers, Democratic Ethos

\section{Introduction}

I $\mathrm{n}$ the West, a shift from liberal to modern, and even postmodern, conceptions of the right to freedom of religion or belief can currently be witnessed (Paulsen 2013). These understandings not only constitute a risk for religious liberty, but also to the functioning of liberal democracy as a whole. The right to freedom of religion or belief does not just have an individual dimension, which is of vital importance, but also communal dimensions (e.g. Norton 2016; Schwartzman, Flanders, and Robinson 2016; Yildirim 2017). These other aspects of religious freedom allow civil society organizations, consciously or unconsciously, to function as a check on the government. Moreover, civil society organizations serve as so-called "seedbeds of virtue" (Glendon and Blankenhorn 1995), which are necessary for a democratic society, as a liberal democracy is ultimately dependent on a virtuous citizenry.

In what follows, I will elaborate on the different conceptions of the right to freedom of religion or belief which can historically be distinguished. Next, the consequences of the most recent shifts in these religious freedom conceptions for liberal democracy are set out. To be able to appreciate the effects of such changes entirely, however, the article starts out by sketching the basic Judeo-Christian anthropology that underlies Western constitutional and political orders, despite the noticeable institutional and other differences that also characterize these systems of government. The article ends with some concluding observations.

\section{The Role of Anthropology}

In addition to its crucial individual aspects, the universal right to freedom of religion or belief also protects the so-called associational and institutional dimensions of religious freedom. As Professor of International Law and Human Rights Johan D. van der Vyver $(2013,105)$ has explained, the associational aspect of the right to freedom of religion or belief promotes "a collective group right (it vests in individuals as members of the religious community) and

\footnotetext{
${ }^{1}$ Corresponding Author: Hans-Martien ten Napel, P. O. Box 9520, Institute of Public Law Section of Constitutional and Administrative Law Leiden Law School, Leiden, 2300 RA, The Netherlands. email: h.m.t.d.tennapel@law.leidenuniv.nl
}

The International Journal of Religion and Spirituality in Society

Volume 8, Issue 3, 2018, http://religioninsociety.com

(C) Common Ground Research Networks, Hans-Martien ten Napel,

Some Rights Reserved (CC BY-NC-ND 4.0). Permissions: support@cgnetworks.org

ISSN: 2154-8633 (Print), ISSN: 2154-8641 (Online)

http://doi.org/10.18848/2154-8633/CGP/v08i03/25-33 (Article) 
includes (a) the right to practice one's religion, in association with other members of the religious community, and (b) the right to form, join and maintain religious associations." Institutional religious freedom, on the other hand, "is an institutional group right (the right vests in a religious institution as such) and...requires of the state not to interfere in the internal affairs of religious institutions" (105).

When thinking about the significance of collective religious freedom for liberal democracy, however, the best place to start is not the right to freedom of religion or belief as such. Before considering how a particular constitutional and political order is shaped or ought to function, it is of crucial importance to ask oneself the question on which anthropology it rests (cf. Pahman 2017). In the case of Western orders, which in their current forms originated in the seventeenth and eighteenth centuries, this anthropology was still heavily influenced by Christianity. It is thus not an exaggeration to argue that, together with Humanism, Christianity-itself, of course, in turn, marked by Judaism - lies at the foundation of the liberal constitutional and political orders as we by and large still know them today (Pera 2008).

According to Judeo-Christian anthropology, man is created in the image of God and therefore possesses infinite human dignity. However, as the Bible also teaches, the creation is fallen and man sinful. It is not difficult to see the connection between these two vital elements of the human condition and how, for example, the American constitutional and political order has been designed: "If men were angels, no government would be necessary. If angels were to govern men, neither external nor internal controls on government would be necessary," according to The Federalist No. 51 (Wills 1982, 262). More generally, it is hardly possible to understand the origins of modern notions of human rights and separation of powers, among other things, without taking this religious heritage into account (McConnell 2001). The Old Testament provided religious, civil, and dietary laws to guide the believer in the proper way to live. In contrast, the New Testament provided a way for the "law" to be written on the heart of humanity through change brought about by a spiritual rebirth. Western democracies have been influenced to some degree by the values and truths expressed in both the Old and New Testaments.

In the West, ties between Christianity and Humanism, intellectually intertwined during the Scholasticism of the Middle Ages, have converged into a kind of Christian Humanist view of humanity. Humanism naturally tends to be more optimistic about human nature, as it does not (necessarily) recognize the existence of a transcendent dimension that imposes limits on individual autonomy. The opposite views of Biblical Christianity and Secular Humanism, i.e. the hopelessness of humankind absent a relationship to a transcendent God active in human history as opposed to humanity capable of perfecting itself absent a deity, has remained. Thus, it is increasingly evident that Humanism today is secularizing society to the extent that it devalues Christianity and frequently opposes many of its values (Kraynak 2001, 124).

Before moving on to the liberal constitutional and political orders, however, it is necessary to distinguish at least two more essential characteristics of Christian anthropology. The first one is that man is a spiritual being, who is naturally inclined to search for the truth about him or herself and the world, both concerning her origins and her destination. The second characteristic is that man is a social being, meaning that he can only realize his full potential in community with others. That these are not merely theoretical notions, is proven by the fact that they can be witnessed if we look around us at the organization of society.

The first thing that strikes the eye if one takes a look at the organization of society is the importance of the family. Children are born into families, and for the first eighteen years or so of their lives, they will typically be raised by their parents. From a certain age onwards, the children will go to school, which can be regarded as a second major institution in society, like the family. In the case a child is born into a religious family, the church, mosque, or synagogue is likely to equally play a role in the first years of his or her life. It is here where, for example in the case of the Christian religion, the child may be baptized and ideally brought to public confirmation of his or her faith in front of the congregation or parish. 
Economic activity of man leads to still more societal institutions. As families, regardless of their composition or how it develops in the course of time, will need to make a living for themselves and feed their offspring, they are likely to search for paid work. In many cases, this will be work with a private employer. Just like a person is formed both emotionally and intellectually within institutions such as the family and school, businesses are also crucial institutions of which human beings can become a part and in the process further engage in the search for meaning and development of their personalities.

In the-admittedly simplified - narrative thus far, there has been no reference to government. In the Christian tradition, the right to religious freedom in both its individual and communal dimensions is seen as a natural right, which precedes the state, rather than as being granted by the state (Wolterstorff 2012a). Given the fallen nature of creation and the ensuing sinfulness of man, sooner or later the establishment of a government is inevitable to physically and otherwise protect both human beings and the different societal institutions identified above. The government will, however, have to recognize the pre-existing right to religious freedom of human beings and societal institutions (Skillen and McCarthy 1991). If the state accepts religious liberty as a natural right, it cannot infringe upon this right, even if its ambitions and commitments may suggest doing so. If to the contrary, one perceives the right to freedom of religion or belief as granted by the state, the state can also withdraw its guarantees and protections in favour of other policy priorities and rights.

\section{Paulsen's Theory of Religious Freedom}

Michael Paulsen, a leading US scholar of constitutional interpretation, has developed an interesting theory of religious liberty that is very much in line with what has been argued above about Christian anthropology. According to Paulsen (2013), no proper protection of the right to freedom of religion or belief is possible, unless a society acknowledges the existence of religious truth. In other words, it needs to do justice to the anthropological fact of life that human beings are spiritual truth-seekers. To this purpose, the state has to acknowledge the "priority of God" by recognizing religious freedom as a natural right preceding itself.

Acknowledging the priority of God also implies that the state should not interfere with how human beings pursue the truth about their origins and destinations by choosing sides one way or another. Instead, it needs to remain neutral concerning the choices citizens make by respecting the principle of separation of church and state. To be sure, this notion can take different forms in the context of the various cultural and historical contexts of Western societies (Soper, Den Dulk, and Monsma 2017). However, should the state choose sides in the pursuit of truth by its citizens, it no longer acknowledges the priority of God but instead grants itself priority over God. In other words, to recognize the priority of God, the state as much as possible will need to be tolerant towards the different religions and beliefs to which its citizens adhere.

If a state acknowledges the priority of God, and remains neutral in religious affairs, then this is in conformity with the liberal conception of religious liberty. This does not necessarily hold true for what today is regarded as the "liberal" position. The classical liberal view referred to here can rightly be regarded as the liberal position in the original meaning of the term. The difference with a preliberal conception of religious liberty is not that the liberal state acknowledges the priority of God; in the preliberal understanding of religious freedom, the priority of God is recognized as well. Unlike what is the case in the liberal state, under preliberal circumstances, the state is not neutral in religious affairs, however. Instead, the preliberal state imposes its definition of truth upon the whole of society. Only the liberal conception of the right to freedom of religion or belief acknowledges the priority of God, while equally principally remaining neutral in religious affairs.

The liberal conception of religious freedom became characteristic of the liberal constitutional and political orders as they took shape across the West during the seventeenth and eighteenth centuries. More specifically, Paulsen $(2013,1167)$ refers to the United States as the 
prime example of such an order. In contrast, many of the people who immigrated to the United States did so because they came from European and other societies in which a preliberal conception of religious freedom was in place. This historical background explains why in the United States the liberal conception of religious freedom has long been held in high regard. Until today, religious freedom is regarded by many as the "first freedom" (McConnell 2000).

In recent decades, however, according to Paulsen $(2013,1171)$ the United States has developed in the direction of what he calls a modern conception of religious freedom. Characteristic of a modern conception is that the state no longer acknowledges the existence of religious truth and thus the priority of God. Due to the secularization of society, what was formerly regarded as "truth-seeking," increasingly has come to be seen as the pursuit of more or less subjective preferences. This phenomenon can adequately be described with the help of the Oxford Dictionaries Word of the Year 2016: "post-truth." Although it may not quite be the original meaning attached to this term, ${ }^{2}$ we are also living in a "post-truth" era, in that the search for objective truth has largely given way to subjective preferences.

It is crucial to see that such a post-truth era does not imply that the modern state is no longer tolerant. Rather, in a post-truth era, it is to a considerable degree regarded as legitimate that each person can develop their lifestyle. However, as the different preferences are seen as entirely subjective, the claims of someone who still wishes to live according to an objective truth will be met with increasing suspicion. Such suspicion means that the right to freedom of religion or belief inevitably becomes controversial because it is not evident why religious preferences would deserve different protection from other preferences. Once it becomes unclear what are the "ultimate questions," with which religions are concerned, all opinions present themselves as equally valuable. Still, religious convictions may well continue to be protected, simply as this seems to be the nice thing to do towards the-somewhat backward-people who for the time being still stick to them (Paulsen 2013, 1171).

Thus, just like during the seventeenth and eighteenth centuries when Western societies developed from a preliberal towards a liberal conception of religious freedom, the United States is currently moving in the direction of a modern conception of religious freedom as identified above. Theoretically, it is possible to distinguish a fourth conception of religious freedom. Characteristic of this postmodern conception is that it does not acknowledge the existence of religious truth. The difference with the modern conception of religious freedom is that it is also no longer tolerant of the different religious beliefs in society (Paulsen 2013).

The second characteristic makes a comparison with the preliberal conception of religious freedom appropriate. As we have seen, in a preliberal conception of religious freedom the state is not tolerant because it privileges one religious truth above all other religious truths that may be espoused in that society. In a postliberal conception of religious freedom, the state does not privilege a religious truth but subscribes to the idea of secularism. As a result, the level of toleration of other religious views in society may end up being even lower than in a preliberal state, as secularism becomes in effect the established religion.

To Paulsen, the postmodern conception of religious freedom is not merely a theoretical matter. According to him, several European countries have already developed in this direction, France being a prime example (Paulsen 2013). The explanation for this fact is that the degree of secularization in European countries is higher than that in American society. Indeed, for several decades the United States was regarded as an exception to the secularization paradigm held by social scientists that modern societies would inevitably secularize. Although secularization currently has become visible in the United States as well, various European countries are still well ahead in this respect (Bagehot 2016).

To the extent that Paulsen's theory of religious freedom holds true, we are witnessing an intriguing development. Less than thirty years ago, after the fall of the Berlin Wall in 1989, expectations were widespread that liberalism would prevail not just in, but also beyond, the West

\footnotetext{
${ }^{2}$ See: https://en.oxforddictionaries.com/word-of-the-year/word-of-the-year-2016.
} 
(Fukuyama 1992). When it comes to religious freedom, however, we are today instead seeing preliberal constitutional and political orders beyond the West (Hirschl 2010). Moreover, the United States and Europe are arguably developing in the direction of modern and postmodern conceptions of religious freedom respectively.

While such developments in the West have consequences for the individual dimension of religious freedom, the implications for the communal dimension of religious freedom are potentially even more serious. The reason for this is that liberalism, rooted in part in Christian anthropology, recognizes the fact that man is a social being and also desires to associate with others while searching for, or abiding by, religious truth. When the role of Christianity in society diminishes in a democracy, its citizens will increasingly come to be seen as autonomous individuals. The reason for this is that, as we have seen, Humanism does not (necessarily) recognize the existence of a transcendental dimension which imposes limits on such autonomy. Consequently, the need for protection of the communal dimension of religious freedom will no longer be recognized. It will be regarded as an obstacle to the unfettered emancipation of the individual (Calo 2014).

\section{Consequences for Liberal Democracy}

In light of the above, one possible line of research would be to investigate the extent to which Paulsen's observations hold true empirically, both in different European states and in the United States. Such an effort is not what the present article sets out to do. Rather, it accepts the various propositions put forward by Paulsen as a priori plausible, and looks at the potential consequences for the functioning of liberal democracy instead (cf. Ten Napel 2017). Two consequences will be discussed, the first of which is the impact on the separation of powers within liberal constitutional and political orders. The second is that it hampers societal institutions in their vital function of, indirectly, generating and cultivating democratic ethos.

As far as the doctrine of separation of powers is concerned, in mainstream constitutional law, this doctrine is usually applied to state organs only (Ten Napel and Voermans 2015). It is understood that state power should not be concentrated in one organ, but instead be divided among the three traditional branches of government, i.e. the legislative, the executive, and the judiciary. This idea is linked to Christian anthropology because the fact that creation is fallen and man sinful implies that "power tends to corrupt and absolute power corrupts absolutely," as the nineteenth-century British politician Lord Acton once wrote. ${ }^{3}$

This form of separation of powers is without doubt of great importance, as is illustrated by the fact that it has perhaps found its clearest expression in the US Constitution, and is set out in the famous and still relevant Federalist Papers (Wills 1982). As was argued in the second section, one cannot properly understand liberal constitutional and political orders by focusing only on the government, however. The government, which sooner or later is instituted, is supposed to serve and protect its citizens and the different societal institutions which by then are already in place.

These societal institutions form a check on the government in their own right, in that even before the state becomes divided into three branches, power is already de facto divided between these societal institutions and the state (Carlson-Thies 2010). Of course, it could be argued-as is mostly done - that this preliminary division of powers does not belong to the realm of constitutional law since most of these institutions are not created by public law but rather by human need (e.g. Möllers 2013). That, however, represents a rather narrow view of what a liberal constitutional and political order is all about. Indeed, such thinking runs the risk of missing what is perhaps its most fundamental characteristic. Of course, the principles of democracy, the rule of law, human rights, and an independent judiciary are all essential elements of what a form of government needs to qualify as a liberal constitutional and political order.

\footnotetext{
${ }^{3}$ See: http://oll.libertyfund.org/quote/214.
} 
There is reason to believe, however, that from the beginning the role which societal institutions fulfil as a check on the government has also been a fundamental characteristic of Western orders (Garnett 2009). As noted earlier, church-state relations have historically taken shape differently in the United States than in Europe. Also, within Europe at least three different models of church-state relations can be discerned: a separationist model, a model of establishment, and a pluralist model. The explanation for this lies precisely in the fact that, for example, in France, England, and the Netherlands different public theologies have led to rivalling visions of the role to be played by civil society organizations in a liberal democratic state (Soper, Den Dulk, and Monsma 2017). Putting too much emphasis on these differences may prevent us from seeing what these different Western orders have in common, i.e. the notion that religion potentially has a role to play not just in the private but also in the public domain (Ten Napel 2017). Liberal states will vary in the degree in which they facilitate civil society organizations in doing so, but no such state will deny the contributions that such organizations can make. Thus, in recent decentralization attempts, authority and tasks are sometimes also delegated to civil society organizations, and as a result of ensuing government regulation of such delegation civil society organizations, if anything, become more rather than less part of the legal system and the state.

Following the rise of the administrative state in Western governments during the twentieth century, an increase in the powers of the state has meant that the early division of the state into three branches has been less effective in protecting individual human rights. As somehow all three traditional branches represent the state, the inequality of arms between an individual and the state today is now greater than ever before. The reason for this lies in the fact that the executive has increasingly come to share the rule-making power, which originally belonged to the legislature. The judiciary is equally involved in rule-making, while often resembling in composition the views of the majority in the legislature (Postell 2017).

Paradoxically, as has already been pointed out by Tocqueville (1805-1859), the fact that a state is democratically organized - as is the case in liberal constitutional and political orders - in itself does not sufficiently help to avoid the risk of tyranny. Contrary to what is commonly believed today, a secular democracy absent of Christian religious principles is not the cure for the legitimation problems of the state, but rather tends to magnify the legitimacy problem of the state. That is, the absence of a healthy division of powers between societal powers and the same state that is supposed to prevent a democratic majority from infringing upon the rights of the minority. Thus, these societal institutions take on a constitutional significance in addition to their primary tasks.

It is here that the connection with religious freedom conceptions becomes manifest. Under a liberal religious freedom conception, societal institutions are provided the space to fulfil their constitutional function, in addition to their primary tasks. Once a modern or postmodern concept of freedom starts to prevail, societal institutions will inevitably come under pressure, and find it harder to fulfil their constitutional function of checks and balances within the government. As a result, human flourishing is likely to diminish, as it may not be long before citizens are no longer able to be truth-seekers in the way they are naturally inclined.

The second consequence of changing religious freedom conceptions for the functioning of liberal democracy is just as serious. Liberal democracy is a form of government that presupposes a virtuous citizenry. Although in a liberal democracy the state is supposed to remain neutral when it comes to different religious convictions in society, these convictions are necessary to promote a democratic ethos without which a liberal constitutional and political order cannot function. Western orders cannot generate this ethos among their citizens by themselves, without infringing upon the principle that the liberal state cannot express itself religiously without being perceived as indoctrinating its citizens (Hall 1992).

Instead, it is clear that to generate and cultivate democratic ethos, societal institutions are of vital importance, starting with families, churches, and schools. Economic institutions play a role as well, in that they stimulate a responsible attitude among citizens, and give them a stake in the 
maintenance of a constitutional and political order that makes it possible for a market economy to function in the way it is supposed to in a free society. The more the secular administrative state expands while abandoning its religious, particularly Christian, foundations, the more societal lifelines run the risk of eroding.

Although the role of societal institutions is vital in a liberal democracy, it is hardly an exaggeration to claim that it is often religion that animates these institutions. It is for this reason that Tocqueville has argued that religion of the Jewish and Christian type is perhaps the most important institution in a liberal constitutional and political order (Kahan 2015). The more the modern or postmodern state becomes all powerful and irreligious, the less Judeo-Christianity can impact the day to day relationships of individual citizens and groups. The reason is that secularism tends to relegate religion to the private sphere, when in fact it needs to play a necessary role in public life as well.

Politics in the original, Aristotelian meaning of the term, is about rival conceptions of the good. Christian anthropology demands that politics retain this character, to the extent that human beings not only pursue the truth in their private lives but also desire to pursue the truth in political life. In order to achieve this goal, religious arguments and considerations must not be banned from politics, but instead be allowed a place at the table in addition to other worldviews in society (Wolterstorff 2012b). It is only in that way that human beings can reach their destination, the unfettered truth in their capacity as citizens.

At the same time, the Christian religion has made it possible for liberal democracies to promote meaningful polities. Although in a liberal democracy the state itself remains neutral concerning the different religious and other convictions in society, these religious convictions themselves make it in at least some cases possible for the same state to nevertheless contribute to the common good (Duke 2017). The alternative of an extensive relativism of society will make true human flourishing nigh on impossible. It will ultimately only allow citizens to serve their self-interest, which is not in conformity with the way they are meant to live.

Thus, it is submitted that the constitutional significance of societal institutions also lies in the fact that they function as "seedbeds of virtue" (Glendon and Blankenhorn 1995). By laying the foundations for a virtuous society, religious, and other institutions contribute to the legitimation of the liberal constitutional and political orders. Also, these institutions serve as checks on the government. A liberal religious freedom conception forms the best guarantee for societal institutions that they will be able to (also) fulfil their constitutional function. In this sense, Paulsen's thesis of development in the direction of modern and postmodern religious freedom devoid of religion creates a clear and present danger for Western orders (Anderson 2017).

\section{In Conclusion}

Increasingly, the right to freedom of religion or belief is facing criticism, certainly in academia (see, e.g. Sullivan et al. 2015). Such criticism can hardly come as a surprise if Paulsen's theory of religious liberty holds true. In a society that no longer acknowledges the existence of religious truth, it is only to be expected that sooner or later the whole point of the right to freedom of religious expression or belief will no longer be accepted. Alternatively, one will start to consider ways of protecting "ethical integrity" in general (Laborde 2015), in which case the result is roughly the same, in that no special protection of religious freedom is likely to remain.

This article has argued that the shifts in religious freedom conceptions which are currently taking place in Western societies, not only constitute a risk for the right to freedom of religion or belief but also to the functioning of liberal democracy as a whole. Christian anthropology teaches that human persons are not just truth-seekers for themselves, but also for society as a whole. To succeed in this, citizens need institutions that nourish them and cultivate their virtues. To the extent that these institutions are protected by the right to religious freedom, they also make it possible for liberal democracy to contribute to the common good and thus human flourishing. 
Under a modern or postmodern religious freedom conception, liberal democracy is increasingly less able to do so. Such a trend has already become so manifest, that even authors who do continue to acknowledge the existence of religious truth have started to consider a future without liberalism. Sometimes this means a withdrawal from public life into smaller communities, in other cases an attempt to return to the politics of the premodern era (Dreher 2017; Simpson 2015). Despite good intentions, it is in neither case entirely clear what the implications will be for the common good and thus for the flourishing of human society as a whole.

\section{REFERENCES}

Anderson, Ryan. 2017. "The Crisis of Liberty in the West." The Heritage Foundation, Lecture, No. 1280, March 7, 2017.

Bagehot. 2016. "This Sceptic Isle." The Economist, August 13. https://www.economist.com /britain/2016/08/13/this-sceptic-isle.

Calo, Zachary R. 2014. "Constructing the Secular: Law and Religion Jurisprudence in Europe and the United States." EUI Working Paper RSCAS 2014/94.

Carlson-Thies, Stanley. 2010. "Liberty or Liability: The Future of Institutional Religious Freedom." Cardus, December 22. (Article Discontinued)

Dreher, Rod. 2017. The Benedict Option: A Strategy for Christians in a Post-Christian Nation. New York: Sentinel.

Duke, George. 2017. "The Common Good." In The Cambridge Companion to Natural Law Jurisprudence, edited by George Duke and Robert P. George, 10203-11135. Cambridge: Cambridge University Press.

Fukuyama, Francis. 1992. The End of History and the Last Man. New York: The Free Press.

Garnett, Richard W. 2009. "Religious Freedom, Church Autonomy, and Constitutionalism." Drake Law Review 57 (4): 901-11.

Glendon, Mary Ann, and David Blankenhorn, eds. 1995. Seedbeds of Virtue: Sources of Competence, Character, and Citizenship in American Society. Lanham, MD: Madison Books.

Hall, Timothy L. 1992. "Religion and Civic Virtue: A Justification of Free Exercise." Tulane Law Review 67 (1): 87-134.

Hirschl, Ran. 2010. Constitutional Theocracy. Cambridge, MA: Harvard University Press.

Kahan, Alan S. 2015. Tocqueville, Democracy, and Religion. Oxford: Oxford University Press.

Kraynak, Robert P. 2001. Christian Faith and Modern Democracy. Notre Dame, IN: University of Notre Dame Press.

Laborde, Cécile. 2015. "Religion in the Law: The Disaggregation Approach." Law and Philosophy 34 (6): 581-600.

McConnell, Michael W. 2000. "Why is Religious Liberty the 'First Freedom'?" Cardozo Law Review 21 (4): 1243-65.

2001. "Old Liberalism, New Liberalism, and People of Faith." In Christian Perspectives on Legal Thought, edited by Michael W. McConnell, Robert F. Cochran, Jr., and Angela C. Carmella, 5-24. New Haven: Yale University Press.

Möllers, Christoph. 2013. The Three Branches. A Comparative Model of Separation of Powers. Oxford: Oxford University Press.

Norton, Jane Calderwood. 2016. Freedom of Religious Organizations. Oxford: Oxford University Press.

Pahman, Dylan. 2017. Foundations of a Free \& Virtuous Society. Grand Rapids, MI: Acton Institute. 
Paulsen, Michael Stokes. 2013. "The Priority of God: A Theory of Religious Liberty." Pepperdine Law Review 39 (5): 1159-1222.

Pera, Marcello. 2008. Why We Should Call Ourselves Christians. The Religious Roots of Free Societies. New York: Encounter Books.

Postell, Joseph. 2017. Bureaucracy in America. The Administrative State's Challenge to Constitutional Government. Columbia, MO: University of Missouri Press.

Schwartzman, Micah, Chad Flanders, and Zoë Robinson, eds. 2016. The Rise of Corporate Religious Liberty. Oxford: Oxford University Press.

Simpson, Peter L. P. 2015. Political Illiberalism. A Defense of Freedom. New Brunswick: Transaction Publishers.

Skillen, James W., and Rockne M. McCarthy, eds. 1991. Political Order and the Plural Structure of Society. Atlanta, GA: Scholars Press.

Soper, J. Christopher, Kevin R. den Dulk, and Stephen V. Monsma. 2017. The Challenge of Pluralism. Church and State in Six Democracies. 3rd ed. Lanham, MD: Rowman \& Littlefield.

Sullivan, Winnifred Fallers, Elizabeth Shakman Hurd, Saba Mahmood, and Peter G. Danchin, eds. 2015. Politics of Religious Freedom. Chicago: The University of Chicago Press.

Ten Napel, Hans-Martien. 2017. Constitutionalism, Democracy and Religious Freedom. To Be Fully Human. London: Routledge.

Ten Napel, Hans-Martien, and Wim Voermans, eds. 2015. The Powers That Be. Rethinking the Separation of Powers. A Leiden Response to Möllers. Chicago: The University of Chicago Press.

Vyver, Johan D. van der. 2013. "Constitutional Protections and Limits to Religious Freedom.” In Law, Religion, Constitution. Freedom of Religion, Equal Treatment, and the Law, edited by W. Cole Durham, Silvio Ferrari, Cristiana Cianitto, and Donlu Thayer, 105-22. Farnham: Ashgate.

Wills, Garry, ed. 1982. The Federalist Papers by Alexander Hamilton, James Madison and John Jay. New York: Bantam Books.

Wolterstorff, Nicholas. 2012a. "Christianity and Human Rights." In Religion \& Human Rights. An Introduction, edited by John Witte, Jr. and M. Christian Green, 42-55. Oxford: Oxford University Press.

2012b. Understanding Liberal Democracy. Essays in Political Philosophy. Oxford: Oxford University Press.

Yildirim, Mine. 2017. The Collective Dimension of Freedom of Religion. A Case Study on Turkey. London: Routledge.

\section{ABOUT THE AUTHOR}

Dr. Hans-Martien ten Napel: Associate Professor, Institute of Public Law Section of Constitutional and Administrative Law, Leiden Law School, Leiden, The Netherlands 


\section{The International Journal of Religion and}

Spirituality in Society aims to create an intellectual frame of reference for the academic study of religion and spirituality and to create an interdisciplinary conversation on the role of religion and spirituality in society. It is intended as a place for critical engagement, examination, and experimentation of ideas that connect religious philosophies to their contexts throughout history in the world, places of worship, on the streets, and in communities. The journal addresses the need for critical discussion on religious issues-specifically as they are situated in the present-day contexts of ethics, warfare, politics, anthropology, sociology, education, leadership, artistic engagement, and the dissonance or resonance between religious tradition and modern trends.
Articles published in the journal range from the expansive and philosophical to finely grained analysis based on deep familiarity and understanding of a particular area of religious knowledge. They bring into dialogue philosophers, theologians, policymakers, and educators, to name a few of the stakeholders in this conversation.

The International Journal of Religion and Spirituality in Society is a peer-reviewed, scholarly journal. 